\title{
ANNOUNCEMENTS
}

In 1975 the International Commission on Radiological Protection (ICRP) published its Publication 23, the Report of the Task Group on Reference Man. Publication 23 is about 15 years out of date, because the references cited end around 1970. At its 1984 meeting, the ICRP approved the formation of a new task group to revise and update this publication, with completion expected in about three years.

The revision will include more emphasis on variations due to age, sex, and other individual differences in anatomical and physiological data and in the gross and elemental composition of tissues. The emphasis in Publication 23 is on data for radiation workers, and the new emphasis reflects that radiation doses to the whole population are of increasing interest to the ICRP and national bodies interested in radiation protection.

We wish to solicit information from users of ICRP Publication 23 , including workers in the medical and biological sciences outside radiation protection who have used the document. In order that the revised document be accurate and complete, it is important that we get advice from as many users as possible. The present task group would appreciate hearing about any errors, omissions of important information, or shortcomings in Publication 23 or of relevant new data not included in Publication 23.

Please write to the task group chairman: C. R. Richmond, Chairman, Task Group on Revision of Reference Man, Oak Ridge National Laboratory, P.O. Box X, Oak Ridge, TN 37831.

The XXIIIrd Meeting of the Latin American Pediatric Research Society will be held in Villa La Angostura, Neuquén, Argentina, November 13-16, 1985. For further information contact: Dr. Alejandro M. O'Donnell, CESNI, Santa Fé 2992-4 (1425), Buenos Aires, Argentina.

The Federation of American Societies for Experimental Biology will again present a series of Summer Research Conferences designed to meet the demand of experimental biologists for intimate and detailed analysis of current research in areas of intense scientific interest. The conferences, held weekly at the Vermont Academy in Saxtons River, VT, will be limited to an attendance of 150 persons and will be by invitation upon application. A conference fee of $\$ 260$ per person covers one week's room, board and registration. For additional information, a complete program and application form, see the February issue of FEDERATION PROCEEDINGS, Volume 44, Number 2, or contact Robert W. Krauss, 9650 Rockville Pike, Bethesda, MD 20814 (301) 530-7093

\section{NEUROTRANSMITTERS (June 9-14)}

Chairman: Bruce Howard, UCLA Medical School

Vice-chairman: William O. McClure, University of Southern California

Regulation of Neurotransmitter Metabolism I\&II. A. Tank, N. Weiner, T. Joh, E. Lewis, E. Diliberto, R. Zigmond, B. Collier, D. Jendon; Neuropeptides. R. Axel, J. Roberts, G. Sutcliff, R. Scheller, J. Douglas, L. Eiden, R. Evans; Synaptic Vesicle Structure. D. Aunis, C. Creutz, V. Whittaker, D. Njus; Transport and Storage. S. Parsons, S. Schuldiner, P. Dannies, B. Kanner, G. Rudnick; Neurotransmitter Release and Membrane Retrieval I\&II. R. Siraganian, P. Greengard, B. Howard, R. Holz, T. Reese, J. Meldolesi, H. Winkler, C. Unsworth, R. Miller; Modulation of Release. D. Michaelson, M. Dubocovich, J. Brown, J. Cooper, M. Livingstone; Neurotoxins. W. McClure, J. Dolly, E. Yavin, D. Yoshikami.

MICRONUTRIENTS: TRACE METALS (June 16-21)

Chairman: Edward Harris, Texas A \& M University

Vice-chairman: Robert Cousins, University of Florida
Iron Absorption, Metabolism and Utilization. P. Saltman, $H$. Munro, E. Morgan, G. Bates; Metabolism and Function of Copper. J. Prohaska, M. Linder, R. Rucker, M. Ettinger; Biological Functions of Selenium. J. Rotruck, R. Burk, H. Cohen; Workshop: Methods of Nutritional Assessment. C. Veillon, D. Gordon, W. Mertz, O. Levander; Zinc Homeostasis and Function. R. Cousins, B. O'Dell, M. Hambidge, I. Bremner; Workshop: Approaches to the Study of Metabolism of Trace Metals. F. Nielson, E. Morgan, A. Prasad, J. Spears; Trace Metals in Reproduction, Growth and Development. J. Apgar, P. Gullino, L. Hurley, K. Falchuk; Abnormalities in Trace Metal Metabolism. I. Sternlieb, D. Danks, M. Failla; Role of Trace Metals in Disease Resistance and Therapy. J. Sorenson, G. Brewer, G. Fernandes, D. McMurray.

SMOOTH MUSCLE (June 23-28)

Chairman: Julius Allen, Baylor College of Medicine

Vice-chairman: R. Kent Hermsmeyer, University of Iowa

Contractile Proteins. D. Hartshorne, R. Murphy, J. Stull, P. DeLanarolle, K. Campbell; Excitation-Contraction Coupling. D. Harder, G. Haeusler, C. Van Breeman, R. Paul, T. Godfraind; Mechanics. B. Johansson, F. Fay, R. Meiss, P. Dobrin, M. Mulvaney; Calcium Localization. V. Kreye, L. McGuffee, K. Morgan, M. Sturek, R. Phair; Ion Pumps. A. Brading, A. Jones, G. Siegel, S. Navran, N. Speralakis; Membrane Receptor Excitation Mechanisms. C. Cohen, P. Abel, J. Singer, T. Bolton, H. Kuriyama; Development, Hypertrophy and Protein Production. R. Bevan, G. Owens, G. Gabella, R. Bagby, C. Seidel; Hypertension. H. Overbeck, M. Pamnani, W. Stekiel, S. Gray, W. Halpern.

LYMPHOCYTE \& ANTIBODIES (June 30-July 5)

Chairman: Henry Wortis, Tufts University School of Medicine

Vice-chairman: Cox Terhorst, Harvard Medical School

Strategies for Inserting Genes. R. Flavell; Rearrangement and Expression of the Immunoglobin Repertoire. F. Alt; Antigen Presenting Cell Phenotypes. M. Dorf; B-Cell Activation. D. Parker, A. DeFranco, C. Cowing, A. Abbas, R. Chesnut, B. Malynn; Molecules Involved in T-Cell Activation. C. Terhorst, T. Mak, W. Greene, L. Cantley; The Function of Ly1 B-Cells. C. Sidman, D. Sherr, L. Herzenberg, E. Vitetta; Cytotoxic T-Cell Effector Functions. P. Henkart, E. Podack, A. Greenberg; Epstein Barr Virus \& B-Cell Transformation. D. Thorley-Lawson, E. Kieff, J. Sullivan, G. Lenoir; HLA Gene Structure \& Disease. B. Dupont.

\section{SOMATIC CELL GENETICS (July 7-12)}

Chairman: Thomas Caskey, Baylor College of Medicine

Vice-chairman: Phillip Coffino, University of California/San Francisco

Oncogenes. I. Verma, I. Sigal, C. Sherr, T. Kataoka; Somatic Cell Selection Workshop. P. Coffino; Cellular Receptors. A. Ullrich; Tissue Specific Gene Regulation. W. Schaffner, T. Maniatis, D. Baltimore, P. Chambon; Gene Walking Workshop. H. Lehrach; Transgenic Mice. F. Constantini, R. Kraumlauf, R. Jaenisch, M. Evans. Recombination. R. Rothstein, F. Alt, M. Capecchi, M. Liskay; Transgenic Workshop. F. Constantini; Gene Transfer. T. Caskey, D. Miller, R. Mulligan, R. Kellems; Cellular Immunity. S. Tonegawa, T. Mak, W. Green, D. Raulet; Vector Development and Usage Workshop. D. Miller; Gene Mapping. J. Gusella, D. Drayna, D. Housmann, H. Lehrach, F. Collins; Plant Somatic Cell Genetics. L. Bogorad, R. Chaleff, R. Fraley.

\section{DEVELOPMENTAL NEUROBIOLOGY (July 14-19)}

Chairman: Nicholas Spitzer, University of California/San Diego

Vice-chairman: Lynn Landmesser, University of Connecticut Lineage Relationships in Vertebrates and Invertebrates. $N$. Spitzer, D. Weisblat, K. Herrup; Lineage Probed with Molecular 